\title{
Design of Multimedia Animation Metal Reinforcement to Improve Learning Quality
}

\author{
Ariyano, A. Suherman \\ Mechanical Engineering Department \\ Faculty of Technical and Vocational Education \\ Universitas Pendidikan Indonesia, West Java, Bandung, INDONESIA \\ email: ariyano_iyan@yahoo.co.id
}

\begin{abstract}
Difficulty engineering student in Materials Engineering courses were related to learning materials that seem abstract. Learning the atomic crystal structure is very important to determine the material properties, in particular the mechanical properties or strength of the material. This study focused on increasing the quality of learning Materials Engineering, in particular metal reinforcement. Specific target of this research is to produce a multi-media learning animation atomic structure. Research procedures using research and development approach, carried out in two stages. The results of the first stage of Multi Media Animation (MMA) on the metal reinforcement material and its influence on mechanical properties. MMA has been through stages of evaluation and development through Focus Group Discussion (FGD) involving media experts and practitioners.
\end{abstract}

Keywords—interactive multimedia, material engineering, atomic crystal.

\section{INTRODUCTION}

Engineering materials are necessary and are basis for mechanical engineering study program. Generally, engineering material are required especially related to mechanical and technological properties of materials, especially metals. All the above material properties are determined by micro atomic structure. Explanation of these concepts are represented in pictures and theories that generally describe abstract events. Difficulties in understanding abstract, complex, and dynamic concepts are the problems in the learning of engineering materials.

Abstract, complex, and dynamic concepts of atoms are possible to be easily comprehended using multimedia animation on the computer. The specific animation media for such material is currently not available. Based on this issue, multimedia animation is highly possible to be an alternative solution for the existing problem.

Citing the opinion of Rowntree, categorized teaching media into five groups called Modes, which include: human interaction, reality, pictorial, written symbols, and sound recordings [1]. Currently, the development of learning tools is available and is easier to use, so the trend of teachers designing and implementing their own homemade animation will continue [2]. This development trend is easily combined with a broader understanding of how these tools can help the learning process so that the use of animation and simulation in the classroom will continue growing. Multimedia in learning is widely used because it has many advantages [3]. Similar thing was stated by [4] [5] "multi media in general uses multiple media including text, graphics, animations, images, video, and sound to present information." Meanwhile, according to [6], media in the context of learning is defined as a language, then multimedia in this context is defined as a multilingual, that is, there is a language that is easily understood by the senses of hearing, sight, smell, touch, and so forth.

Multimedia technology which contains multimedia animation is expected to be able to overcome the obstacles in the learning process [7]. For example the movement of atoms is abstract, difficult to understand or difficult to comprehend using symbols or theories shown in the books, but with the help of multimedia animation, it is expected to be easier to understand due to the aid of motion that can be observed based on the abstract concepts. According to Edgar Dale's cone of learning, what is learned tends to be remembered better, up to $50 \%$ of the material taught for more than two weeks, if the learning involves the media in which there are elements of audio and visual (Visual Receiving), it can even achieve $70 \%$ if the students are involved in giving opinion or discussion, and can reach $90 \%$ if they are involved in simulation or do the process [8].

\section{METHODS}

This research is a developmental research using research and development (R \& D) approach.

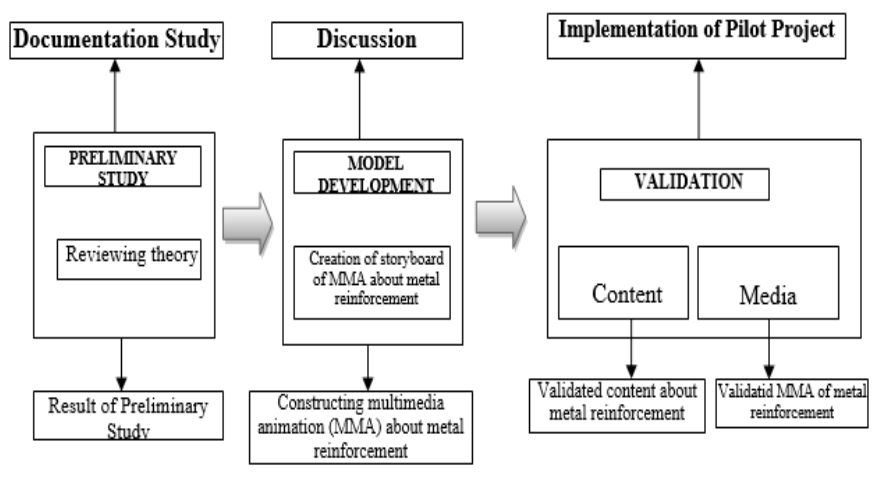

Fig. 1. Research Design 
The steps planned as in Figure 1 include: preliminary study (assessment of theory, collection of materials, identification, analysis, and construction of material about metal reinforcement), construction of storyboard (writing storyboard, organizing materials, planning audio, editing, proofreading), application to the computer (designing and programming), evaluation and development through Focus Group Discussion (FGD) involving media experts and practitioners. The next step is testing the multimedia animation regarding the sources and the effective learning media for the material about metal reinforcement (product validation). This test is related to the material content which will be facilitated using MMA and the test related to the construction of media.

\section{RESULTS AND DISCUSSION}

\section{A. Description of Material Experts' Data Judgment}

Data judgment by Material Experts in this study is the information to assess the content of the materials used in the study. Data judgment was assessed by Expert Material Lecturers from DPTM UPI. Data judgment was used as a basis if the material contents in multimedia animation and learning materials were advisable to be used in the research. The processing of Material Experts' data judgment in general is presented in Table 1.

TABLE I. Results of THE PROCESSING OF MATERIAL EXPERTS' DATA JUDGMENT

\begin{tabular}{|c|c|c|c|c|c|c|}
\hline \multirow{2}{*}{ Gains } & \multicolumn{5}{|c|}{ Assessment } & \multirow{2}{*}{ Total } \\
\hline & $4(\mathrm{SL})$ & $3(\mathrm{~L})$ & $2(\mathrm{KL})$ & $1(\mathrm{TL})$ & 0 (STL) & \\
\hline Quantity & 2 & 8 & 0 & 0 & 0 & 10 \\
\hline Score & 8 & 24 & 0 & 0 & 0 & 32 \\
\hline & & & & \multicolumn{2}{|c|}{ Maximum Score } & 40 \\
\hline & & & & \multicolumn{2}{|c|}{$\begin{array}{c}\text { Percentage of } \\
\text { advisability }\end{array}$} & $80,00 \%$ \\
\hline
\end{tabular}

Based on the data processing of the result of Material Experts' judgment, it can be said that, in terms of material, multimedia animation and learning materials created is advisable to be used in learning about Metal Reinforcement.

\section{B. Description of Media Experts' Data Judgment}

Data judgment by Media Experts in this study is the information to assess multimedia in terms of multimedia design assessed by Media Expert Lecturers from UPI. This data judgment was used as a basis that the multimedia animation created is advisable to be used in the research. If the multimedia animation created, in terms of multimedia design, is advisable to use, the multimedia animations created can be said to be valid in terms of multimedia design. Result data of judgment by Media Experts can be seen in Table 2.
TABLE II. Result of The Processing of Media Experts' Data JUDGMENT

\begin{tabular}{|c|c|c|c|c|c|c|}
\hline \multirow[b]{2}{*}{ Gains } & \multicolumn{5}{|c|}{ Assessment } & \multirow[b]{2}{*}{ Total } \\
\hline & $4(\mathrm{SL})$ & $3(\mathrm{~L})$ & $\begin{array}{c}2 \\
(K L)\end{array}$ & $1(\mathrm{TL})$ & $0(\mathrm{STL})$ & \\
\hline Quantity & 3 & 14 & 0 & 0 & 0 & 17 \\
\hline Score & 12 & 42 & 0 & 0 & 0 & 54 \\
\hline & & & & \multicolumn{2}{|c|}{ Maximum Score } & 68 \\
\hline & & & & \multicolumn{2}{|c|}{$\begin{array}{c}\text { Percentage of } \\
\text { Advisability }\end{array}$} & $79,41 \%$ \\
\hline
\end{tabular}

Based on the processing of Media Experts' data judgment, it can be said that in terms of media design, the multimedia animation created is advisable to be used in the learning about Metal Reinforcement.

\section{MMA Model about Metal Reinforcement}

TABLE III. ANIMATION STORYBOARD OF METAL REINFORCEMENT

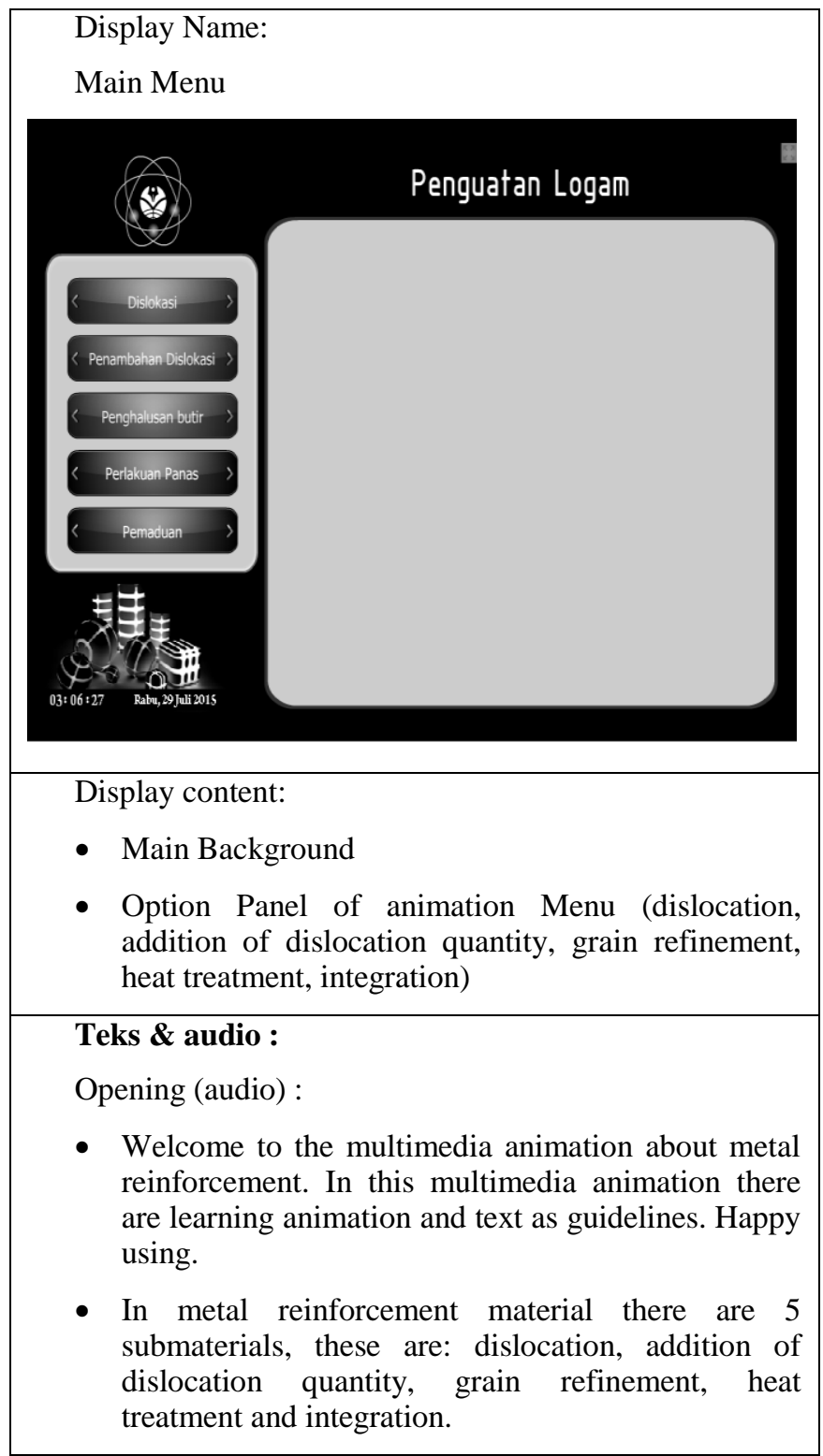




\section{Navigation Button}

- Dislocation button is a button to enter the option menu of animation material consisting of the definition and properties of dislocation

- Dislocation quantity addition button is a button to enter the option menu of animation material consisting of the definition of dislocation quantity addition and the animation of how to add dislocation quantity.

- Gain refinement button is a button to enter the option menu of animation material consisting of the definition of grain refinement, animation of grain refinement using cold and animation of grain refinement using heat

- Heat treatment button is a button to enter the option menu of animation material consisting of the definition of heat treatment and animation of heat treatment.

- Integration button is a button to enter the option menu of animation material consisting of the definition of integration, animation of how to interties and animation of how to substitute.

\section{RESULTS AND DISCUSSION}

Students' concept mastery that uses multimedia animation in the learning process is associated with features and characteristics of multimedia animation itself. The multimedia animation is a media resulted from the combination of printing and computer technology that combines text, images or static and dynamic visual and audio, and all of which is controlled by computer, so that the process involves many interactivities [9]. Multimedia animation is also thought to be able to stimulate students to do exercises, simulations and so forth, "... animation can add a sense of realism, can stimulate to conduct exercises, laboratory activities, simulations and so on [10]". It is influenced by the results of theoretical (image) manipulation into realistic animations so that is attracts animation users to learn.

Based on the description of learning media, it can be said that the use of multimedia animation media in learning can improve students' concept mastery about abstract materials. This is supported by data results of MMA development that facilitates the students in anticipating the mastery of abstract concepts. This is in line with Kemp and Dayton's theory [9], which suggests that "media improves new readibility skill."

Animation media of materials about the definition of Metal Reinforcement gives the example of the movement of atoms of crystal structure. This animation of the movement of atoms will further clarify and facilitate learners to better understand the learning material. Based on the description of media presentation, it can be said that learning on the material about Metal Reinforcement containing the movements of these atoms can be understood if it is assisted with animation. Meanwhile, without animation media, the learning process on the movement of atoms cannot be conducted optimally. This is in line with the statement by Reiber (1994) in [11] concerning the animation, that is, 'animation can assist the learning process if only the students perform cognitive processes aided by animation, while without animation, the cognitive process cannot be performed.' Students' concept mastery cannot be separated from the more concrete description of multimedia animation. It is supported by Dale' cone of experience (1969) in [9], which shows that the more concrete the description of a learning media in a learning process is, the more experience the learners gain. The use of more concrete instructional media will result in the increase of better concept mastery.

\section{CONCLUSION}

Based on the steps taken in this study, it is concluded that MMA about Metal Reinforcement can be projected to facilitate learners (college students) in mastering the concept of the material about metal reinforcement.

\section{REFERENCES}

[1] Syaodih N.S. (2004). Kurikulum dan Pembelajaran Kompetensi. Bandung: PT Kesuma Karya.

[2] Falvo, DA. (2008). Animations and simulations for teaching and learning molecular chemistry. International Journal of Technology in Teaching and Learning. Vol. 4, No.1. pp. 68-77.

[3] Berk, R. A. (2009). Multimedia teaching with video clips: TV, movies, YouTube, and mtvU in the college classroom. International Journal

[4] Widodo W. (2010). Pengembangan Model Pembelajaran "Mikir" pada Perkuliahan Fisika Dasar untuk Meningkatkan Keterampilan Generik Sains dan Pemecahan Masalah Calon Guru SMK Program Keahlian Tata Boga, Disertasi. Sekolah Pascasarjana UPI, tidak diterbitkan.

[5] Mahrus AA. (2010). Multimedia \& Animasi. http:// ebookbrowse.com. [15:30. 18 Januari 2013].

[6] Munadi Y. (2013). Media Pembelajaran (Sebuah Pendekatan Baru). Jakarta: Referensi.

[7] Munir. (2010). Kurikulum Berbasis Teknologi Informasi dan komunikasi. Bandung: Alfabetha.

[8] Fadel C. (2008). Multimodal Learning Through Media: What the Research Says. Diunduh dari www.cisco.com/web/strategy/docs/education, [16:34, 11 Februari 2015].

[9] Arsyad A. (2010). Media Pembelajaran. Jakarta: PT. Raja Grafindo Persada.

[10] Sudjana, N. \& Rivai, A. (1989).Teknologi Pengajaran. Bandung: Sinar Baru.

[11] Susilana, R. \& Riyana, C. (2009). Media Pembelajaran. Bandung: CV. Wacana Prima. 